\title{
The Economics of Control Fraud
}

Robert E. Prasch ${ }^{\dagger}$

\author{
Presented to the Annual Meetings of: \\ Associação Keynesiana Brasileira, São Paulo, August 2014
}

Date of this draft: September 25, 2014

"A [thieving] man must be something worse than a simpleton to still ply his trade on the high-roads, exposed to all sorts of annoyances on the part of the gensdarmes, when manufacturing and financial enterprises offer such a magnificently fertile field to the activity of imaginative people."

-- Emile Gaboriau, Other People's Money (1874, trans. 1900, p. 337; Gaboriau is credited with inventing the modern detective novel. The book quoted is, I believe incorrectly, thought to be one of his minor works).

\begin{abstract}
Fraud can take a variety of forms. For that reason we can expect that the individuals, or groups of individuals, engaged in it will undertake a variety of strategies depending upon the circumstances in which they find themselves. For this reason the "checks and balances" presumed to be adequate for detecting and suppressing fraud in any given firm or market may work passingly well in one instance but be less effective in another. Pursuant that notion, this paper will begin with a brief taxonomy of fraud before turning to a more in-depth discussion of the most pernicious form of fraud - Control Fraud.
\end{abstract}

\section{Firms Defrauding Customers: Predation}

The first form of fraud, one that is highly familiar, is that of a corporation or firm defrauding its own customers. Here the firm is selling a product, service, or financial instrument that it knows, or should know, is materially defective or deficient. Such frauds are most easily perpetrated when the key underlying qualities of the product being sold cannot be discerned by most "reasonably informed" buyers. Hidden qualities facilitate the process of foisting defective products or predatory financial contracts upon uninformed or systemically misinformed consumers or investors. Economists have, rather cavalierly, assumed that "the market" will readily identify such deceptions or frauds and they have further assumed that "reputation effects" are sufficiently potent that deceptive purveyors of goods or services, while annoying or even costly in the sort term, will soon

\footnotetext{
* I would like to thank Prof. Fernando Ferrari (UFRGS), for setting up my visit to Brazil and his hospitality throughout my stay. I would also like to thank the President of the AKB, Prof. Jose Luis da Costa Oreiro (UFRJ) for putting together an excellent conference. Additionally, I wish to thank Prof. Falguni A. Sheth (Hampshire College) and Mark Setterfield (Trinity Univ. and the New School) for their comments. Finally, I must thank William K. (Bill) Black for his path-breaking work on the economics of fraud. Much of what follows came out of my many conversations with him along with extended meditations on those conversations. All errors are, however, my own.

${ }^{\dagger}$ Professor of Economics. Middlebury College. Middlebury, VT. 05753; rprasch@ middlebury.edu.
} 
be out of business. Hence, it is supposed, enlightened self-interest should be sufficient to regulate or police such firms.

This rather smug assumption concerning "the power of the market" to inform and guide behavior toward ideal outcomes was - for a time -- disrupted by the publication of George Akerlof's "Lemons" paper (Akerlof 1970). There, the future Nobel Laureate demonstrated that if critical and costly-to-acquire information was asymmetrically distributed between the seller and buyer, it would induce self-protective behaviors on the part of rational, but partially informed, buyers. Specifically, the latter would shy away from entire classes of products, thereby undermining entire markets.

There after a debate emerged as to whether or not compensating institutions and behaviors-in the form of third party inspections or investments by firms in "credibility" or "branding" -would be sufficient to control such problems. Importantly, there is historical evidence that consumer trust in markets in hard-to-evaluate goods such as processed foods or drugs has been enhanced in the wake of states imposing regulations in the form of truthful advertising or prohibitions of certain practices (Law 2003).

\section{Customers Defrauding Firms: Misrepresentation and Insurance Fraud}

The second variety of fraud is similar, but opposite to, the above. Here customers defraud firms. A prominent instance of this form of fraud is insurance fraud. This includes falsely reporting losses such as car accidents, stolen traveler's checks, owners deliberately burning down insured but failed business properties, and so forth. In contrast to the first category, I know of no instance where an economist has argued that "market forces" conjoined with "reputation effects" render penalties against the individuals who engage in such deeds redundant and hence unnecessary.

Nevertheless, given the challenges and costs of proving fraudulent conduct, firms have developed ways to mitigate it. These include the pre-screening of customers, inserting substantial deductibles into standardized insurance contracts, and retaining private detectives to investigate instances of probable fraud. Clearly it is not possible or cost-effective to reduce the probability of such events to zero, but the continued existence of markets in insurance and travelers' checks suggests that the costs associated with insurance fraud has not been debilitating.

\section{Employees Defrauding a Company: Embezzlement}

This third variety of fraudis usually called embezzlement. In this case one or more employees illegally diverts some portion of the firm's cash flow to themselves. So, for example, a bank's cashier may devise a way to skim from the cash drawer during his or her shift. Or a middle 
manager may develop a way of underreporting the profits of his operating unit to the firm's accountants, thereby creating a flow of "off the books income" that can be appropriated. ${ }^{1}$ In general, the goal of these efforts is to increase the income of the employee at the expense of the company (revenge by a disgruntled employee is a parallel but separate motivator).If we assume that our employee is "rational" in the economic sense, we can suppose that he or she is maximizing the following sum:

Annual Income = Legitimate Income + Bezzle - Dollar Value of the Costs of Managing and Covering Up the Scheme - Dollar Value of the Expected Costs in the Event of Detection

Clearly, firms have an incentive to monitor their employees to prevent or mitigate embezzlement. Over the years and depending upon the nature of the business, firms have devised various methods to detect fraud. Internal controls \& procedures, "checks and balances," periodic outside audits, and surprise inspections of inventory, are all differing strategies to check or minimize employee fraud.

By contrast to the next and final category, what is distinct about this variety of fraud is that the employee, or cabal of employees, engaged in it are operating within a detection environment that is substantially outside of their control. As mere employees or middle managers, these persons are rarely in a position to change, much less nullify, their firms' detection apparatus. At best, they can act in a manner that deflects attention away from their illicit activities.

One common way by which embezzlers have deflected attention from themselves is by outperforming their peers. It is human nature and good business practice to reward, rather than punish, superior performance. Senior managers and CEOs know that spontaneous reviews or performance audits are irksome, and that they clearly convey a sense of distrust. As such, they might undermine a superior employee's loyalty to the firm and its mission. Consequently, top employees are typically subject to less oversight and are likely to be granted more leeway when seemingly minor infractions of the rules are uncovered. All things being equal, the embezzling employee can prolong their criminal activities, so long as they restrict their ambitions to redirecting a modest portion of the firm's revenue toward themselves.

Given human nature and the above incentive structure, it is possible to imagine a scenario in which an outstanding employee engaged in an ongoing but modest amount of fraud over an extended time period may, in the final analysis, add value to the firm and - through their greater productivity - to the economy overall. In such instances, the overall economic effect of the fraud is merely redistributive. After all, if total productivity the same or even modestly enhanced, the only

\footnotetext{
${ }^{1}$ John Kenneth Galbraith (1954) labeled all such ill-gotten gains “The Bezzle.” 
lasting effect of the illegal actions of the embezzling employee would be a redirection of a portion of the funds set aside for shareholder dividends or senior management's bonus pool.

\section{Management Defrauding Their Own Firm: Control Fraud}

The fourth and final variety of fraud is the most fascinating, most threatening economically and politically, and - somewhat strangely - the most neglected. It has been neglected by the mainstream of economists and (in the United States at least) most prosecutors. This is the instance of C-Suite executives(CEOs, CFOs, COOs, etc.) defrauding the firms or corporations they lead. Such practices have been termed "Control Fraud" or" Looting" (Black 2005; Akerlof and Romer 1993).

In contrast to the varieties of fraud summarized above, Control Frauds are instances wherein C-Suite executives are themselves the instigators, perpetuators, and guiding force behind the defrauding of their own firms. This, it turns out, inverts our "common sense" concerning the detection and suppression of fraud. Why? Because C-Suite executives are, nominally, in charge of setting up the controls charged with detecting and suppressing fraud. This, of course, greatly reduces the chances that the fraud will be detected in a timely manner. Several implications follow. One is that the size of the fraud can be exponentially larger. A second is that control frauds have the capacity to suborn the personnel and offices nominally assigned to oversight and fraud detection. Indeed, the situation is likely to become so perverse that these same persons and offices are likely become - willingly or inadvertently - contributors to the fraud (although they are less likely to be its beneficiaries). Consider what this means: in the event of a control fraud, the firm is transformed into the primary instrument through which the fraud is conducted (Wheeler and Rothman 1982).

\section{Control Frauds Are, By Far, the Greatest Threat to the Economy}

Unfortunately, the perverse situation described in the previous paragraph is not the end of the story. If control frauds manage one or more of the most prominent firms in a particular region, state, or nation, its C-Suite executives will be able to exert disproportionate political influence. Inevitably, and unsurprisingly, this influence will be directed toward protecting and extending the regulatory frameworks and accounting practices that facilitate the continuation of their fraudulent schemes.

Being large, prominent, and - at least on paper -- growing firms, control frauds can exert disproportionate sway over outside controls. How? In the private sector, this takes place through the CEO's ability to hire and fire outside consultants, accountants, and ratings agencies. At times, frauds have even directed the firing of specific individuals. Pressured by one of their most important 
clients and sources of fee income, these outsiders will repress their knowledge of any fraud they could or did observe (Geis 2013). As the saying goes, "One hand washes the other."

In the public sector, control frauds bring substantial political pressure onto the - speaking charitably -- poorly informed, misinformed, or merely opportunistic politicians sitting on the key legislative committees charged with the writing of regulations, setting of accounting rules and standards, and overseeing the budgets allocated for, and appointees nominated to, crucial regulatory agencies (Calavita, Pontell, and Tillman 1997: 94-121; Correia 2014). As may already be evident, the potential consequences (and costs) of the existence of one or more prominent control frauds on the political environment, integrity of the regulatory agencies, and the efficiency and transparency of markets, can readily become substantial. Even worse, as outside controls come to be suborned, weakened, or otherwise compromised, an opening is created for the emergence of even more control frauds. William Black describes this as the creation of a criminogenic environment, one wherein a "race to the bottom" gathers momentum. The consequences for the economy, again by contrast to the simple embezzlements described above, can be little short of catastrophic (Black 2005).

Another element of control fraud that is - as if by convention - neglected their pronounced tendency to destroy the firm, and in all likelihood the industry within which the firm operates. This destruction takes several forms. William Black has explained that control frauds maximize their bezzle, and lower their chances of detection, by undertaking plans and projects that are complex, difficult to price, and designed to fail (Black 2005). ${ }^{2}$ His contention is well supported by what we know of the $S \& L$ disaster of the 1980s and the several machinations associated with the origination, securitization, and sale of mortgages in the 2000s. But, in the interests of brevity, I will restrict the argument presented here to considering the incentives faced by a control fraud hiring senior executives.

Consider how a control fraud would approach the tricky question of hiring a COO, CFO, Head Accountant, or Head Legal Advisor. Let us begin by assuming that they conduct themselves like any other CEO, and hire the most qualified and experienced person available in the market. Once hired, this highly qualified person will exhibit one of two characteristics that, in turn, support three possible strategies, all of them bad from the perspective of the control fraud.

Suppose (1) that the person hired is fully capable, as assumed above, but turns out to be honest. This capable senior executive will soon discern that the CEO is a fraud who is using the firm as an instrument for their own enrichment. Being honest, they could go to the authorities and report what they have seen. However, what we know of the experiences of whistleblowers and

\footnotetext{
${ }^{2}$ Space considerations do not allow a proper exploration of this subject. It has been given fuller consideration in a longer manuscript that the author hopes to publish in the not-too-distant future.
} 
American politics affirm that it is far from obvious that their brave effort to report the fraud will doom the fraudulent CEO and his or her accomplices. However, the actions of this honest senior executive will oblige the control fraud to divert time, money, and attention to defensive operations. These will include a massive public relations campaign, one that includes an aggressive smearing of the whistleblower's reputation, the fending off those regulators who find the report plausible, and the sending of even more contributions to well-situated and friendly politicians, etc. And, of course, there is a small but real chance that it could all end badly, as it eventually did for Charles Keating. ${ }^{3}$

Alternatively (2) the capable senior executive hired is honest, but has no wish to endure the very public and well-financed destruction of their reputation and career that will inevitably accompany their decision to become a whistle-blower. However, they also know that remaining silent and at the firm is not an option for two reasons. First, their job implicates them in the fraud to the extent that they must handle and endorse too many falsified or tainted documents. Second, they know that with the inevitable failure of the firm and the emergence of an ensuing scandal, their professional colleagues will harbor doubts about their ability and/or honesty. Hence, their best option is to leave, and leave quickly. Understanding this, vigilant regulators have come to learn that rapid turnover among senior executives may be an indicator of fraud at a financial institution.

Another (3) possibility is that the recently hired and capable senior manager might be dishonest. While, from the perspective of the Control Fraud, this would certainly forestall the difficulties described in (1) and (2), it creates its own set of problems. A capable but dishonest senior executive can be expected to quickly identify the fraud and then demand a share of the bezzle! This is bad news for two reasons. First, it means that the Control Fraud must share some of his dishonestly-acquired revenues. Second, following the well-known economic logic wherein "underpriced common pools"(in this instance the bezzle) are over-exploited, too many control frauds embezzling one firm may so greatly increase the overall size of the fraud that their collective action could undermine their ability to deceive outside controls, including those who may be - for economic or political reasons -strongly disinclined to perceive what is actually occurring.

What, then, is the dominant hiring strategy for a Control Fraud who must, after all, staff the firm's top offices? By now, the answer should be clear: it is to hire people who are stupid or otherwise incompetent. Of course, incompetent senior executives will contribute to the eventual demise of the firm, but let us recall that a firm being managed by one or more frauds has already set a course toward failure.

From the perspective of Control Frauds incompetent senior managers have several desirable qualities. First, incompetents are unlikely to notice that the firm is being catastrophically

\footnotetext{
${ }^{3}$ One cannot help but feel somewhat sorry for Charles Keating. It was his bad luck that George H. W. Bush did not see fit to appoint the likes of Eric Holder and Lanny Breuer to senior positions at the Department of Justice.
} 
mismanaged. Hence, the Control Fraud need not share the bezzle with them. Indeed, if they are promoted exclusively from within the firm, and for that reason have no basis for comparison with the corporate culture of honestly-managed firms, there is a chance that they may never learn of the fraud that surrounds them. As such, they can sincerely take up the role of "useful idiots" across a wide variety of venues, including after-dinner speeches or television appearances about the evils of "overzealous regulators." Second, most (although not all) incompetents retain some notion that they may not have deserved the high office to which they were appointed. Sensing this, they are extremely grateful to their benefactor - the fraudulent CEO -- and can be expected to exhibit a ferocious loyalty to him or her.

\section{Conclusion}

Economists, mainstream and even post-Keynesians, have unduly neglected the role of fraud in their analysis. While some of this neglect must be attributed to the dispositions or classidentifications of academics, some of it may derive from a failure to appreciate the differences between the several varieties of fraud and how they matter. In particular, the failure to understand and account for the particularly pernicious case of control fraud undermines economists' ability to appreciate the power of fraud to destroy the trust that is necessary to the operation of a modern financial system. Moreover, and for the same reason, economists have for too long undervalued the central role that regulators play in the proper functioning of modern financial markets.

\section{References}

Akerlof, George, and Paul M. Romer, (1993). "Looting: The Economic Underworld of Bankruptcy for Profit," Brookings Papers on Economic Activity. No. 2: 1-73.

cross refhttp://dx.doi.org/10.2307/2534564

Black, William K. (2005). The Best Way to Rob a Bank is to Own One. Austin, TX: University of Texas Press.

Calavita, Kitty, Henry N. Pontell, and Robert H. Tilman, (1997). Big Money Crime: Fraud and Politics in the Savings and Loan Crisis. Berkeley, CA: University of California Press.

Correia, Maria. (2014). "Political Connections and SEC Enforcement," Journal of Accounting and Economics forthcoming. cross ref http://dx.doi.org/10.1016/j.jacceco.2014.04.004

Galbraith, John Kenneth. (1954, reprinted 2009). The Great Crash, 1929. Boston: Houghton Mifflin.

Geis, Gilbert. (2013). "Unaccountable External Auditors and Their Role in the Economic Meltdown," Ch. 5 in How They Got Away With It: White Collar Criminals and the Financial 
Meltdown Edited By Susan Will, Stephen Handelman, and David C. Brotherton. New York: Columbia University Press.

Law, Marc. (2003). "The Origins of State Pure Food Regulation," Journal of Economic History v. 63, no. 4 (December): 1103-1130. cross refhttp://dx.doi.org/10.1017/S0022050703002547

Smith, Yves. (2010). Econned. New York: Palgrave Macmillan.

Wheeler, Stanton, and Mitchell Lewis Rothman. (1982). "The Organization as a Weapon in White Collar Crime." Michigan Law Review v. 80, no. 7: 1403-1426.

crossrefhttp://dx.doi.org/10.2307/1288554

Will, Susan, Stephen Handelman, and David C. Brotherton, Eds., (2013). How They Got Away With It: White Collar Criminals and the Financial Meltdown. New York: Columbia University Press. 